\title{
THE ANTIBACTERIAL POTENTIAL OF ESSENTIAL OILS ON PROPIONIBACTERIUM GRANULOSUM STRAINS
}

\author{
Șandru, Daniela Maria ${ }^{1}$ and Panaitescu, Magda ${ }^{2}$ \\ 1"Lucian Blaga” University of Sibiu, Romania, daniela.sandru@ulbsibiu.ro \\ 2Universidad "Latina" de Panama, Rep. de Panama, mpanaitescu@ulatina.edu.pa
}

\begin{abstract}
Gram-positive bacteria Propionibacterium granulosum lives on human skin along with other propionibacteria on the skin, these bacteria are especially important to have healthy skin and occupy some ecological niches. These niches are populated by some pathogenic bacteria. Propionibacterium granulosum bacteria produce some fatty acids that have low molecular weight, bacteriocins and other substances that inhibit some bacteria. The aim of this research is to investigate the microbiological evolution of some essential oils on Propionibacterium granulosum strains. It is observed that the highest values are recorded when $20 \mu \mathrm{L}$ of essential oil is used.
\end{abstract}

KEYWORDS: Propionibacterium granulosum, essential oils, cultures, Origanum vulgare, antibacterial activity.

\section{INTRODUCTION}

Human skin is a large organ of the human body with a wide range of bacteria that have a special role in achieving healthy skin such as: Staphylococcus, Propionibacterium, Corynebacterium and Malassezia (Vowels et al. 1995). Propionibacterium granulosum and Propionibacterium acnes are found especially where there are many sebaceous glands. These glands are several on the face, but Propionibacterium granulosum can also be found in the mouth and prostate, and can influence organs other than the skin (Coates et al. 2002). However, Propionibacterium avidum is more widespread in humid places, such as the armpit, groin and anus where there is more moisture (Oprica et al. 2004). Consistent with the role of maintaining healthy skin, a reduced abundance of Propionibacteria has been observed to be found in small amounts in people with skin diseases. An example would be those with psoriasis, with serious skin diseases and atopic dermatitis (Knobloch et al. 2003). Propionibacteria have been shown to play an important role in skin health, but often these bacteria can cause disease if certain aspects are met. Propionibacterium granulosum often causes some fairly severe skin conditions, and can develop into some diseases, such as acne vulgaris and progressive macular hypomania (PMH), which are due to medical or dental devices, but can also cause some diseases of the skin. soft tissue, for example: sarco disc disease, prostate cancer and some soft tissue diseases (Pauli et al. 2001; Burt et al. 2004; Hammer et al. 1999; Jirovetz et al. 2006; Smith-Palmer et al. 1998; Prabuseenivasan et al. 2006). Some plants have bioactive compounds in their tissues, very important for their fight against microorganisms, being useful to the human body (Goud et al. 2020, Poomanee et al. 2018, Sterarus et al. 2017, Panaitescu et al. 2017).

\section{MATERIALS AND METHODS}

-Essential oils of Bergamot, Melaleuca quinquenervia, Anethum graveolens, Eugenia Caryophyllus, Origanum vulgare

-Bacteria of the species Propionibacterium granulosum, strains Propionibacterium granulosum 43, Propionibacterium granulosum 25, Propionibacterium granulosum 17, Propionibacterium granulosum 37, Propionibacterium granulosum 72 isolated in the Microbiology Research Laboratory, of the Faculty of Agricultural Sciences, Food Industry and Environmental Protection.

Agar Schaedler + Vitamin K3

Schaedler agar and Schaedler agar + Vitamin K3 are prepared from Schaedler broth according to the formula described by Schaedler, Dubos and Costello.

- Tryptone-casein-soy broth $10 \mathrm{~g} / \mathrm{L}$

- Special peptone $5 \mathrm{~g} / \mathrm{L}$

- Yeast extract $5 \mathrm{~g} / \mathrm{L}$

- TRIS buffer $3 \mathrm{~g} / \mathrm{L}$

- Cysteine hydrochloride $0.4 \mathrm{~g} / \mathrm{L}$

- The group has $0.01 \mathrm{~g} / \mathrm{L}$

- Glucose $5 \mathrm{~g} / \mathrm{L}$

- Agar $15 \mathrm{~g} / \mathrm{L}$

- $\mathrm{pH} 7.6 \pm 0.2$

- Vitamin K3 $0.0005 \mathrm{~g} / \mathrm{L}$

- Horse blood 5.5\%.

-The method used was disk diffusion.

This study was performed following the method of Hayes and Markovic (2002). Propionibacterium granulosum cultures were incubated in meat broth supplemented with $1 \%$ glucose and adjusted to produce approximately $1.0 \times 108 \mathrm{CFU} / \mathrm{mL}$.

Plates with Schaedler Agar + Vitamin K3 culture medium were coated with Propionibacterium granulosum inoculum.

-Sterile filter paper discs

They were placed aseptically inoculated plate and impregnated with $10 \mu \mathrm{L} 15 \mu \mathrm{L}, 20 \mu \mathrm{L}$ of each essential oil.

The plates were left at room temperature for 30 minutes to allow pre-diffusion before incubation. Incubation was performed at 37 ${ }^{\circ} \mathrm{C}$ for 72 hours under anaerobic conditions. 
Inhibition diameters were measured in $\mathrm{mm}$ and recorded as mean \pm S.D., (with standard deviation).

\section{RESULTS AND DISCUSSIONS}

In general, essential oils contain a large amount of active components. The difference in antibacterial activity of essential oils may be due to the difference in chemical compositions. The main components of essential oils showed a varied activity in this respect, the results being visible in tables 1,2 and 3.

Table 1. Antibacterial action of Bergamot, Melaleuca quinquenervia, Anethum graveolens, Eugenia Caryophyllus, Origanum vulgare essential oils on Propionibacterium granulosum strains $(10 \mu \mathrm{L})$.

\begin{tabular}{|l|l|l|l|l|l|}
\hline & Bergamot & $\begin{array}{l}\text { Melaleuca } \\
\text { quinquenervia }\end{array}$ & $\begin{array}{l}\text { Anethum } \\
\text { graveolens }\end{array}$ & $\begin{array}{c}\text { Eugenia } \\
\text { Caryophyllus }\end{array}$ & $\begin{array}{c}\text { Origanum } \\
\text { vulgare }\end{array}$ \\
\hline $\begin{array}{l}\text { Propionibacterium } \\
\text { granulosum 43 }\end{array}$ & $12,9 \pm 0,21$ & $15,4 \pm 0,22$ & $18,2 \pm 0,25$ & $12,4 \pm 0,23$ & $14,8 \pm 0,21$ \\
\hline $\begin{array}{l}\text { Propionibacterium } \\
\text { granulosum 25 }\end{array}$ & $11,6 \pm 0,33$ & $16,5 \pm 0,25$ & $18,0 \pm 0,21$ & $12,3 \pm 0,21$ & $14,5 \pm 0,31$ \\
\hline $\begin{array}{l}\text { Propionibacterium } \\
\text { granulosum 17 }\end{array}$ & $13,5 \pm 0,32$ & $17,1 \pm 0,23$ & $18,7 \pm 0,23$ & $12,2 \pm 0,24$ & $15,1 \pm 0,22$ \\
\hline $\begin{array}{l}\text { Propionibacterium } \\
\text { granulosum 37 }\end{array}$ & $12,4 \pm 0,26$ & $16,3 \pm 0,22$ & $18,5 \pm 0,31$ & $11,9 \pm 0,23$ & $15,3 \pm 0,23$ \\
\hline $\begin{array}{l}\text { Propionibacterium } \\
\text { granulosum } 72\end{array}$ & $13,0 \pm 0,23$ & $17,3 \pm 0,21$ & $18,4 \pm 0,26$ & $12,2 \pm 0,24$ & $15,0 \pm 0,21$ \\
\hline
\end{tabular}

As noted in Table 1, the development of Propionibacterium granulosum strains was inhibited by the essential oils studied differently.

The resulting values ranged from a minimum of $11.6 \mathrm{~mm}$ for P.granulosum 25 strain to a maximum of $13.5 \mathrm{~mm}$ for $\mathrm{P}$. granulosum 17 strain when using Bergamot essential oil at a concentration of $10 \mu \mathrm{L}$.

For the same concentration by using the essential oil of Melaleuca quinquenervia, values between $15.4 \mathrm{~mm}$ were obtained in the case of P. granulosum strain 43 and $17.3 \mathrm{~mm}$ in the case of P. granulosum strain 72 .
The use of Anethum graveolens essential oil led to results between $18.2 \mathrm{~mm}$ and $18.7 \mathrm{~mm}$ specific to P. granulosum 43 and P. granulosum 17 strains, respectively.

Following the results obtained when using Eugenia Caryophyllus, values between $11.9 \mathrm{~mm}$ and $12.4 \mathrm{~mm}$ specific to P. granulosum 37 and P. granulosum 43 strains are observed.

In the case of Oreganum vulgare essential oil, the values of inhibition of crop development were in the range of $14.5 \mathrm{~mm}$ for P. granulosum strain 25 and $15.3 \mathrm{~mm}$ for P. granulosum strain 37.

Table 2. Antibacterial action of Bergamot, Melaleuca quinquenervia, Anethum graveolens, Eugenia Caryophyllus, Origanum vulgare essential oils on Propionibacterium granulosum strains $(15 \mu)$.

\begin{tabular}{|l|l|l|l|l|l|}
\hline & Bergamot & $\begin{array}{c}\text { Melaleuca } \\
\text { quinquenervia }\end{array}$ & $\begin{array}{c}\text { Anethum } \\
\text { graveolens }\end{array}$ & $\begin{array}{c}\text { Eugenia } \\
\text { Caryophyllus }\end{array}$ & $\begin{array}{c}\text { Origanum } \\
\text { vulgare }\end{array}$ \\
\hline $\begin{array}{l}\text { Propionibacterium } \\
\text { granulosum } 43\end{array}$ & $18,9 \pm 0,23$ & $21,4 \pm 0,20$ & $22,2 \pm 0,23$ & $17,4 \pm 0,25$ & $14,8 \pm 0,26$ \\
\hline $\begin{array}{l}\text { Propionibacterium } \\
\text { granulosum 25 }\end{array}$ & $17,6 \pm 0,31$ & $22,5 \pm 0,24$ & $22,8 \pm 0,21$ & $17,3 \pm 0,21$ & $14,7 \pm 0,33$ \\
\hline $\begin{array}{l}\text { Propionibacterium } \\
\text { granulosum 17 }\end{array}$ & $16,5 \pm 0,32$ & $21,1 \pm 0,23$ & $22,7 \pm 0,23$ & $16,2 \pm 0,27$ & $20,1 \pm 0,26$ \\
\hline $\begin{array}{l}\text { Propionibacterium } \\
\text { granulosum 37 }\end{array}$ & $17,4 \pm 0,26$ & $21,3 \pm 0,24$ & $22,5 \pm 0,31$ & $16,9 \pm 0,25$ & $20,3 \pm 0,21$ \\
\hline $\begin{array}{l}\text { Propionibacterium } \\
\text { granulosum } 72\end{array}$ & $17,0 \pm 0,23$ & $21,3 \pm 0,21$ & $22,4 \pm 0,26$ & $17,2 \pm 0,28$ & $20,2 \pm 0,22$ \\
\hline
\end{tabular}

Table 2 shows that the development of Propionibacterium granulosum strains was also inhibited by the essential oils used at a volume of $15 \mu \mathrm{L}$.
In the case of the use of Bergamot essential oil, the resulting values ranged from a minimum of $16,5 \mathrm{~mm}$ for $\mathrm{P}$. granulosum 17 strain to a maximum of $17,6 \mathrm{~mm}$ for P. granulosum 25 strain. 
For the same concentration, by using essential oil of Melaleuca quinquenervia, values between $21.1 \mathrm{~mm}$ were obtained for $\mathrm{P}$. granulosum 17 and $22.5 \mathrm{~mm}$ for P. granulosum 25.

The use of Anethum graveolens essential oil led to results of between $22.2 \mathrm{~mm}$ for the P granulosum strain. 43 and $22.8 \mathrm{~mm}$ for P. granulosum strain 25 .
In the case of the use of Eugenia Caryophyllus oil, values between $16.2 \mathrm{~mm}$ and $17.4 \mathrm{~mm}$ specific to P. granulosum 17 and P. granulosum 43 strains are observed.

Origanum vulgare essential oil led to bacterial culture inhibition values of $14.7 \mathrm{~mm}$ for P. granulosum strain 25 and $20.3 \mathrm{~mm}$ for P. granulosum strain 37 .

Table 3. Antibacterial action of Bergamot, Melaleuca quinquenervia, Anethum graveolens, Eugenia Caryophyllus, Origanum vulgare essential oils on Propionibacterium granulosum strains $(20 \mu \mathrm{L})$.

\begin{tabular}{|l|l|l|l|l|l|}
\hline & Bergamot & $\begin{array}{l}\text { Melaleuca } \\
\text { quinquenervia }\end{array}$ & $\begin{array}{l}\text { Anethum } \\
\text { graveolens }\end{array}$ & $\begin{array}{l}\text { Eugenia } \\
\text { Caryophyllus }\end{array}$ & $\begin{array}{l}\text { Origanum } \\
\text { vulgare }\end{array}$ \\
\hline $\begin{array}{l}\text { Propionibacterium } \\
\text { granulosum 43 }\end{array}$ & $23,1 \pm 0,22$ & $26,6 \pm 0,18$ & $28,3 \pm 0,22$ & $23,4 \pm 0,25$ & $24,2 \pm 0,21$ \\
\hline $\begin{array}{l}\text { Propionibacterium } \\
\text { granulosum 25 }\end{array}$ & $21,2 \pm 0,28$ & $25,3 \pm 0,25$ & $28,6 \pm 0,21$ & $20,3 \pm 0,23$ & $24,9 \pm 0,22$ \\
\hline $\begin{array}{l}\text { Propionibacterium } \\
\text { granulosum 17 }\end{array}$ & $23,3 \pm 0,31$ & $27,8 \pm 0,19$ & $28,4 \pm 0,22$ & $21,2 \pm 0,25$ & $25,8 \pm 0,23$ \\
\hline $\begin{array}{l}\text { Propionibacterium } \\
\text { granulosum 37 }\end{array}$ & $22,1 \pm 0,27$ & $26,2 \pm 0,24$ & $28,3 \pm 0,17$ & $20,5 \pm 0,21$ & $25,7 \pm 0,26$ \\
\hline $\begin{array}{l}\text { Propionibacterium } \\
\text { granulosum } 72\end{array}$ & $22,2 \pm 0,24$ & $27,1 \pm 0,27$ & $28,1 \pm 0,16$ & $22,7 \pm 0,26$ & $25,8 \pm 0,25$ \\
\hline
\end{tabular}

Table 3 shows a strong inhibition in the development of Propionibacterium granulosum strains where a volume of oil of $20 \mu \mathrm{L}$ was used.

In the case of the use of Bergamot essential oil, the resulting values were between $21.2 \mathrm{~mm}$ for P. granulosum strain 37 and a maximum of $23.3 \mathrm{~mm}$ for P. granulosum strain 17 .

For the same concentration, using values of Melaleuca quinquenervia essential oil, values between $25,3 \mathrm{~mm}$ were obtained for P. granulosum 25 and $27.8 \mathrm{~mm}$ for P. granulosum 17.

In the case of the use of Anethum graveolens essential oil, results were obtained between $28.1 \mathrm{~mm}$ for P. granulosum strain 72 and $28.6 \mathrm{~mm}$ for P. granulosum strain 25.

In the case of the use of Eugenia Caryophyllus oil, it is observed that these values were between $20,3 \mathrm{~mm}$ for $\mathrm{P}$. granulosum strain 25 and 23,4 $\mathrm{mm}$ for P. granulosum strain 43.

The Origanum vulgare essential oil used led to the inhibition of the development of the strains used at values between $24.2 \mathrm{~mm}$ for P. granulosum 43 and $27.8 \mathrm{~mm}$ specific for P. granulosum 17 and $\mathrm{P}$. granulosum 72 strains.

\section{CONCLUSIONS}

The essential oils of Bergamot, Melaleuca quinquenervia, Anethum graveolens, Eugenia Caryophyllus, Origanum vulgare have antimicrobial action on the Propionibacterium granulosum strains under study, so their use in the cosmetics industry is recommended.

At a volume of $10 \mu \mathrm{L}$ the most significant antibacterial activity was observed in the case of Anethum graveolens essential oil, the most sensitive strain being Propionibacterium granulosum 25, followed by the essential oil of Melaleuca quinquenervia which acted most strongly on the Propionibacterium granulosum strain 72. Essential oil of Bergamot and Eugenia Caryophyllus acted the least on the strains of Propionibacterium granulosum, and that of Origanum vulgare showed intermediate values, the most sensitive strain being Propionibacterium granulosum 37.

At a volume of $15 \mu \mathrm{L}$ results a more pronounced antibacterial activity in the case of essential oils of Anethum graveolens and Melaleuca quinquenervia where the inhibition area is very close, the highest sensitivity being found in the strain Propionibacterium granulosum 25.

At the same volume, the antibacterial action of Origanum vulgare, Eugenia Caryophyllus and Bergamot essential oils increases with percentages between $25 \%$ and $35 \%$.

At a volume of $20 \mu \mathrm{L}$ there is an increase of this activity on average by $50 \%$ compared to the initial volume. The result is a significant increase in the case of the essential oils of Melaleuca quinquenervia and Anethum graveolens, followed by the essential oil of Origanum vulgare, and the lowest values are observed in the case of Bergamot and Eugenia Caryophyllus oils.

\section{REFERENCES}

1. Burt S., Essential oils: their antibacterial properties and potential applications in foods-a review. Int $\mathrm{J}$ Food Microbiol, Vol. 94, pp. 223-253, (2004).

2. Coates P, Vyakrnams S, Eady EA., Prevalence of antibiotic-resistant propionibacteria on the skin of acne patients: 20-year surveillance data and snapshot distribution study. Br J Dermatol, Vol. 246, pp. 840-848, (2002).

3. Goud N.S., Prasad G. (2020). Antioxidant, antimicrobial activity and total phenol and flavonoids analysis of Sambucus nigra (elderberry) Int J Curr Pharm Res, Vol. 12, No.1, pp. 35-37, (2020).

4. Hammer KA, Carson CF, Riley TV, Antimicrobial activity of essential oils and other plant extracts. J Applied Microbiol, Vol. 86, pp. 985-990, (1999). 
5. Jirovetz L, Eller G, Buchbauer G. (2006). Chemical composition, antimicrobial activities and odor descriptions of some essential oils with characteristic floral-rosy scent and of their principal aroma compounds. Recent Res Devel Agronomy Horticulture, Vol. 2, pp. 2-22, (2006).

6. Knobloch K, Pauli A, Iberl B., Antibacterial and antifungal properties of essential oils. Curr Med Chem; Vol. 20, pp. 823-829, (2003).

7. Nord CE, Oprica C., Antibiotic resistance in Propionibacterium acnes. Microbiological and clinical aspects. Anaerobe;Vol. 22, pp. 207-220, (2006).

8. Oprica C, Emtestam L, Lapins J. (2004). Antibioticresistant Propionibacterium acnes on the skin of patients with moderate to severe acne in Stockholm. Anaerobe; Vol. 20, pp. 255-264, (2004).

9. Panaitescu M., Lengyel E., Monitoring the antibacterial activity of Hibiscus Sabdariffa extracts, Management of Sustainable Development Sibiu, Romania, Vol. 9, No.1, pp. 31-34, (2017).

10. Pauli A., Antimicrobial properties of essential oil constituents. Int J Aromather; Vol. 22, pp. 226-33, (2001).

11. Poomanee W, Chaiyana W, Mueller M, Viernstein H, Khunkitti W, Leelapornpisid P., In-vitro investigation of anti-acne properties of Mangifera indica L. kernel extract and its mechanism of action against Propionibacterium acnes. Anaerobe, Vol. 52, pp. 64-74, (2018).

12. Prabuseenivasan $S$, Jayakumar M, Ignacimuthu S., In vitro antibacterial activity of some plant essential oils. BMC Complemen Altern Med; Vol. 6, No. 39, (2006).

13. Ross JI, Eady EA, Cove JH., Clinical resistance to erythromycin and clindamycin in cutaneous propionibacteria isolated from acne patients is associated with mutations in 23S rRNA. Antimicrob Agents Chemother; Vol. 42, pp. 2262-2265, (1997).

14. Smith-Palmer A, Stewart J, Fyfe L., Antimicrobial properties of plant essential oils and essences against five important foodborne pathogens. Lett Appl Microbiol; Vol. 26, pp. 228-222, (1998).

15. Stegăruș D., Lengyel E., The antimicrobial effect of essential oils, upon certain nosocomial bacteria, Conference proceeding, 17-International Multidisciplinary Scientific Geoconference, SGEM 2017, Albena, Bulgaria, Advances in Biotechnology, pp. 1089-1095, (2017).

16. Vowels BR, Yang S, Leyden JJ., Induction of proinflammatory cytokines by a soluble factor of Propionibacterium acnes: implications for chronic inflammatory acne. Infect Immun; Vol. 63, pp. 3258-3265, (1995). 